\title{
Liquid phase organic synthesis of 3,5-disubstituted 1,3,5-thia- diazinane-2-thione derivatives on polyethylene glycol (PEG) support
}

\author{
Hortensia Rodríguez, ${ }^{\mathrm{a}, b^{*}}$ Julieta Coro, ${ }^{\mathrm{a}}$ Margarita Suárez, ${ }^{\mathrm{a} *}$ Roberto Martínez-Álvarez, \\ Nazario Martín, ${ }^{\text {** }^{*}}$ and Fernando Albericio ${ }^{\mathrm{b}, \mathrm{d}, \mathrm{e,f*}}$ \\ ${ }^{a}$ Laboratorio de Síntesis Orgánica, Departamento de Química Orgánica, Facultad de Química, \\ Universidad de La Habana, 10400-Ciudad Habana, Cuba \\ ${ }^{b}$ Institute for Research in Biomedicine, Barcelona Science Park, Baldiri Reixac 10, 08028- \\ Barcelona, Spain \\ ${ }^{c}$ Departamento de Química Orgánica, Facultad de Ciencias Químicas, Universidad \\ Complutense, E-28040 Madrid, Spain \\ ${ }^{d}$ CIBER-BBN, Networking Centre on Bioengineering, Biomaterials and Nanomedicine, \\ Barcelona Science Park, Baldiri Reixac 10, 08028-Barcelona, Spain \\ ${ }^{e}$ Department of Organic Chemistry, University of Barcelona, Martí i Franqués 1-11, 08028- \\ Barcelona, Spain \\ ${ }^{f}$ School of Chemistry, University of KwaZulu-Natal, South Africa \\ E-mail:horten@fq.uh.cu;msuarez@fq.uh.cu,nazmar@quim.ucm.es, albericio@irbbarcelona.org
}

\begin{abstract}
An efficient liquid-phase synthesis of 3,5-disubstituted 1,3,5-thiadiazinane-2-thione derivatives (THTT) is described using soluble polymer support polyethylene glycol (PEG) 5000 via one-pot condensation of PEG-bound free amino acid or PEG-bound tripeptide, a dithiocarbamate and formaldehyde under mild conditions. This procedure affords the target compounds in good yields and high purity with a facile work-up procedure. This synthetic approach has also allowed the efficient preparation of new compounds endowed with two THTT rings linked through the N-3 nitrogen atoms. The structures of all synthesized compounds were unequivocally established by standard spectroscopic techniques.
\end{abstract}

Keywords: Liquid-phase synthesis, 1,3,5-thiadiazinane-2-thione, polyethylene glycol

\section{Introduction}

The development of new synthetic methodologies for the preparation of organic compounds is one of the most important objectives in modern drug discovery. ${ }^{1}$ In this regard there is a lot of interest in the implementation of new processes and new synthetic strategies. In particular, much 
attention has been focused on liquid-phase organic synthesis (LPOS) on soluble polymers since it combines the advantages of classical homogeneous solution methodology (high reactivity and simple analytical procedures) with those of solid-phase organic synthesis (SPOS) (use of excessive reagents, easy isolation and purification of the final products and high stability of the system polymer-supported molecule). ${ }^{2}$ Polyethylene glycol (PEG) with $\mathrm{M}_{\mathrm{w}}=5000 \mathrm{Da},{ }^{3}$ is by far the most widely soluble support employed. It is an inexpensive polymer and an ideal support for liquid-phase combinatorial synthesis because it is easy to functionalize and also resistant to drastic operative conditions. ${ }^{4}$ Furthermore, it is soluble in many organic solvents, such as $\mathrm{CH}_{2} \mathrm{Cl}_{2}, \mathrm{CHCl}_{3}$, tetrahydrofuran (THF), $\mathrm{CH}_{3} \mathrm{OH}$, or $\mathrm{H}_{2} \mathrm{O}$ at room temperature and it can be precipitated from a solution by addition of diethyl ether, tert-butyl methyl ether, propan-2-ol, or hexane. ${ }^{5}$ Due to these features, PEG chemistry has shown a broad-based application, which may be in large part ascribed to the use of PEG-conjugates to deliver drugs, oligonucleotides or enzymes. ${ }^{6}$ The liquid phase method, known for more than 25 years in peptide synthesis, ${ }^{7}$ has been broadly applied to the synthesis of small organic molecules and to combinatorial chemistry. $^{8}$

On the other hand, compounds derived from 1,3,5-thiadiazinane-2-thiones (THTT) have received particular attention due to the pharmacologycal properties they display. It is well known that THTT present antibacterial, antifungal, antimicrobial and antiprotozoal activity ${ }^{9}$ and excellent activities have been obtained in compounds bearing lipophilic groups at the N-3 and hydrophilic ones at $\mathrm{N}-5$ position. ${ }^{10}$ The promising results of antiparasitic bioactivity achieved by THTT derivatives could be attributed to the interaction of cysteine proteinases, present in most groups of parasitic protozoa, ${ }^{11}$ with isothiocyanates, ${ }^{12}$ generated by hydrolysis of the THTT ring in a protic medium. ${ }^{13}$ Notwithstanding, the possible interaction of the released amino acids or dipeptides, attached to N-5 of the THTT ring, with other molecular targets, thereby enhancing the antiparasitic activity observed of these derivatives, should not be ruled out.

In a previous work we have described the synthesis of several 3,5-disubstituted 1,3,5thiadiazinane-2-thiones bearing furfuryl, cyclohexyl, and carboxypentyl radicals at N-3 and carboxyalkyl residues at $\mathrm{N}-5 .{ }^{14}$ The synthesized molecules were evaluated in vitro and in vivo against Trypanosoma cruzi and Trichomonas vaginalis showing significant antiprotozoal activity that, in some cases, was further correlated to a non-specific toxicity effect. ${ }^{15}$ In another study the remarkable cytotoxicity properties of these derivatives against HeLa and HT-29 cells were also tested, ${ }^{16}$ and we have developed a theoretical model to predict the influence of structure on the antitumor activity for this type of compounds. ${ }^{17}$

The antiparasitic properties of some 5-carboxyalkyl-3-furfuryl-1,3,5-thiadiazinane-2-thione against both extracellular promastigotes and intracellular amastigotes of Leishmania amazonensis have also been reported. ${ }^{18,19}$ The results showed that the evaluated compounds exhibited a strong antiproliferative activity on all developmental stages of the parasite.

Following our ongoing project to develop new antiparasitic agents using the THTT ring as the central core, we have also reported the synthesis and biological activity of bis(1,3,5thiadiazinane-2-thiones) derivatives where the two thiadiazinane rings are linked by an alkyl 
chain $^{20}$ or a linear polyamine moiety. ${ }^{21}$ Taking to account the interaction mechanism suggested for this heterocycle, the incorporation of two THTT moiety in the same structure must increase the activity of these derivatives as antiparasitic agents. ${ }^{22}$

We have previously demonstrated the feasibility of the synthesis of thiadiazinane-2-thiones in solution ${ }^{14-16,18-21}$ by reaction of the appropriate amine with carbon disulfide and potassium hydroxide, to give the dithiocarbamate potassium salt, which is not isolated, followed by cyclocondensation with formaldehyde and the selected amino acids or pseudopeptides able to provide the nitrogen atom at the N-5 position of the thiadiazinane ring. Based on experimental evidence and DFT studies, a probable cyclization route to 1,3,5-thiadiazinane-2-thiones in aqueous medium was proposed. ${ }^{23}$ In addition, the conformational features of the THTT by X-ray diffraction and theoretical calculations have also been studied. ${ }^{24}$

Moreover, taking into account the presence of two points of diversity at nitrogens N-3 and N-5 of the THTT, we have developed the solid phase synthesis (SPS) of this molecular scaffold as a first approach to design a THTT-like library, ${ }^{25}$ although its use is limited by two factors: i) the possibility for the starting amines to be properly functionalized for the efficient coupling to the resin and, ii) the low solubility of the amino acids in the solvent employed.

Therefore, within our research program focused on the development of alternative methodologies for the synthesis of nitrogen containing heterocycles, herein we disclose a novel liquid-phase organic synthesis of 1,3,5-thiadiazinane-2-thione derivatives which are obtained in good yields and high purity. To the best of our knowledge, this is the first report on the liquidphase synthesis of THTT compounds.

\section{Results and Discussion}

As illustrated in Scheme 1, an effective liquid-phase organic synthesis of 3,5-disubstituted 1,3,5thiadiazinane-2-thione derivatives has been developed. The soluble polymer support (PEG-OH (PEG), average molecular weight ca. 5000) 1, dissolved in DMF, was coupled with Fmocprotected amino acids 2a-d under $N, N^{\prime}$-diisopropylcarbodiimide (DIC), 4dimethylaminopyridine (DMAP) activation conditions for 45 minutes. The reaction mixtures were purified through a simple precipitation, filtration and ether washing to remove un-reacted reagents and side products. The conversion of terminal hydroxyl groups on PEG was determined by IR analysis to be quantitative. The PEG-bound Fmoc protected amino acid 3a-d showed complete disappearance of the hydroxyl $\mathrm{OH}$ stretching band and the appearance of a strong carbonyl stretching band at $1728 \mathrm{~cm}^{-1}$. Removal of Fmoc from 3a-d was performed with $20 \%$ piperidine in DMF at room temperature for 20 minutes to afford 4a-d. The PEG bound primary amines 4a-d were then incorporated with the solution of dithiocarbamate salt intermediate $\mathbf{6 a , b}$ (not isolated and formed from amine $\mathbf{5}$ and carbon disulfide) and formaldehyde to afford, in a one step procedure, the PEG-bound THTT 7a-h. Upon completion of the reaction, the polymer support was removed from the homogeneous solution by precipitation with diethyl ether and 
filtration to provide the corresponding PEG-bound THTT 7a-h. The target compounds 8a-h were obtained in relatively good yields and high HPLC purity of crude product by cleavage from the PEG support under the treatment of the PEG-bound product 7a-h with a solution of $\mathrm{NaOH}(0.5$ $\mathrm{mol} / \mathrm{L})$. By treatment with $\mathrm{HCl} \mathrm{15 \%}$, the desired 3,5-disubstituted 1,3,5-thiadiazinane-2-thione derivatives 8a-h are obtained. (Table 1).

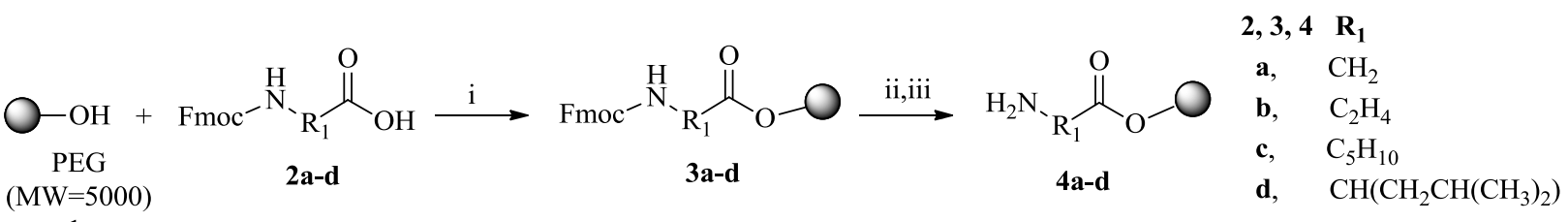

1
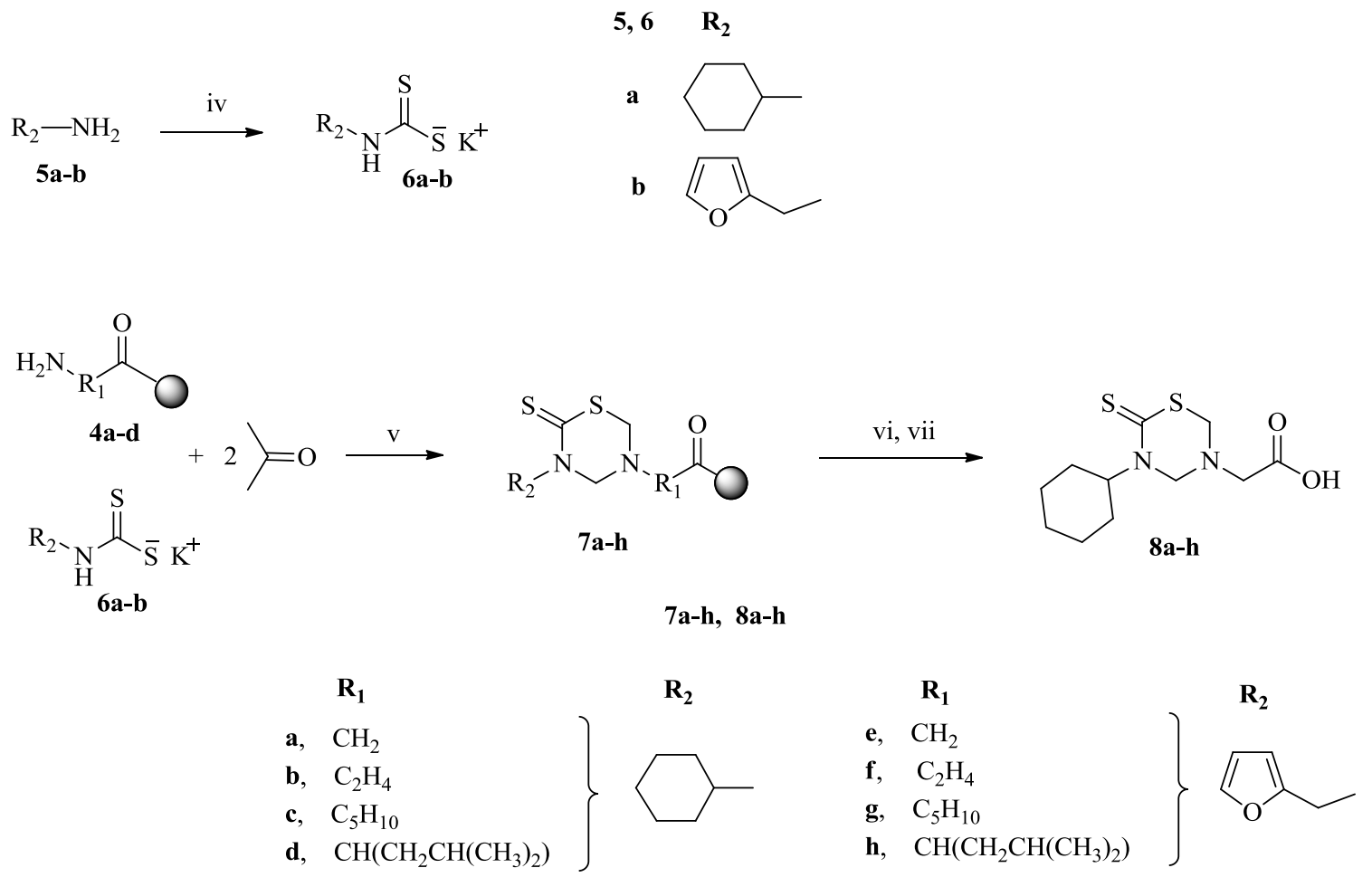

Scheme 1. LPOS of 3,5-disubstituted 1,3,5-thiadiazinane-2-thione derivatives 8a-h. (i) DIC, DMAP, DMF; (ii) Fmoc-deprotected (20\% piperidine in DMF, rt); (iii) Precipitation by addition of ethyl ether; (iv) $\mathrm{CS}_{2}, \mathrm{KOH} 20 \%, \mathrm{H}_{2} \mathrm{O}$, rt; (v) phosphate buffer solution (pH 7.8-8); (vi) $\mathrm{NaOH}$ $0.5 \mathrm{~N}$; (vii) $\mathrm{HCl} 2 \mathrm{~N}$.

As shown in Table 1, the present method allows the synthesis of THTT derivatives 8a-h with similar or slightly higher yields than those previously reported. ${ }^{14}$ According to the formerly reported methodology, ${ }^{14,20}$ these results can be attributed to the relatively low stability of the intermediate dithiocarbamates $\mathbf{6 a , b}$ in solution. ${ }^{1} \mathrm{H}$ and ${ }^{13} \mathrm{C}$ NMR spectra confirmed the 
formation of the THTT ring and their spectroscopic data were identical to those obtained from the products synthesized by following the method previously reported. ${ }^{26,27}$

Table 1. Yields and purities of 3,5-disubstituted 1,3,5-thiadiazinane-2-thione derivatives 8a-h

\begin{tabular}{ccccc}
\hline Compound & $\mathrm{R}_{1}$ & $\mathrm{R}_{2}$ & Yield (\%) & Purity (\%) \\
\hline $\mathbf{8 a}$ & $-\mathrm{CH}_{2^{-}}$ & 40 & 94 \\
$\mathbf{8 b}$ & $-\mathrm{C}_{2} \mathrm{H}_{4}{ }^{-}$ & 64 & 95 \\
$\mathbf{8 c}$ & $-\mathrm{C}_{5} \mathrm{H}_{10^{-}}$ & 65 & 93 \\
$\mathbf{8 d}$ & $-\mathrm{CH}\left(\mathrm{CH}_{2} \mathrm{CH}\left(\mathrm{CH}_{3}\right)_{2}\right)-$ & 56 & 88 \\
\hline $\mathbf{8 e}$ & $-\mathrm{CH}_{2^{-}}$ & 55 & 95 \\
$\mathbf{8 f}$ & $-\mathrm{C}_{2} \mathrm{H}_{4-}$ & 66 & 94 \\
$\mathbf{8 g}$ & $-\mathrm{C}_{5} \mathrm{H}_{10^{-}}$ & 60 & 94 \\
$\mathbf{8 h}$ & $-\mathrm{CH}\left(\mathrm{CH}_{2} \mathrm{CH}\left(\mathrm{CH}_{3}\right)_{2}\right)-$ & & 60 & 87 \\
\hline
\end{tabular}

Taking into account the remarkable antiprotozoal activity exhibited by THTT, and in order to increase the molecular diversity based on the THTT motif, two THTT rings were incorporated into the same molecular structure (bis-THTT). ${ }^{21,22}$ In this work, we have adapted our LPOS strategy of THTT derivatives to expeditious synthesis of two new hybrid structures endowed with two THTT rings, connected through their $\mathrm{N}-3$ atoms by a linear aliphatic backbone $\left(\mathrm{C}_{6} \mathrm{H}_{12}\right)$ and tripeptide residues at N-5 (bis-THTT-tripeptide). The synthesis of the bis-THTT-tripeptides was carried out as shown in Scheme 2 through a polymeric intramolecular reaction taking advantage of the special flexibility of the PEG units. First we carried out the liquid phase synthesis of the peptide sequences 9a and 9b in PEG 5000 as soluble polymer support by means of the coupling/deprotected standard conditions, with treatment of DIC/DMAP for the first residue a DIC/HOBt for the rest as coupling reagents and piperidine $20 \%$ in DMF as Fmocdeprotected solution. All deprotection reactions were carried out for 20 minutes, and all coupling reactions were for 45 minutes. Upon completion of each reaction of the cycle coupling/deprotection, the product mixtures were purified by precipitation and thoroughly washed with diethyl ether to remove unreacted reagents and side products. Polymer substitution levels of $0.36-0.38 \mathrm{mmol} / \mathrm{g}(90-95 \%)$ of the tripeptide secuences 9a-b were measured by spectrophotometric Fmoc. ${ }^{28}$ Progress of the chain assemblies was routinely monitored using the ninhydrin test on small aliquots of the dried isolated intermediates after the acylation and Fmocdeprotection cycles. Not influence in the reaction yield was observed with the presence of a strong nucleophile in a THTT ring formation step. The slightly basic medium of this step (Step v in Scheme 2) and the addition procedure used could influence in this result. To ensure the structure of the two peptides sequence, the crude peptides were analyzed by HPLC-MS after the cleavage treatment of one mg of PEG bound at the peptides sequence. The two peptides were obtained in reasonable purity, 94.2 and $96.7 \%$ for sequence $\mathbf{9 a}$ and $\mathbf{9 b}$, respectively. At the same time, starting from commercially available 1,6-diaminohexane $\mathbf{1 0}$ and carbon disulfide under basic conditions (KOH 20\%), the dithiocarbamic salt intermediate 11 was obtained. Further 
condensation reaction of 11, formaldehyde and the methanol dissolved PEG 5000-bound tripeptide afforded the bis-THTT-tripeptides immobilized in the support 12a,b. Finally, PEGbound products 12a,b were cleaved with $0.5 \mathrm{~N} \mathrm{NaOH}$ solution at room temperature overnight to afford, after acidulation procedure with $\mathrm{HCl}(2 \mathrm{~N})$, target compounds 13a,b in high yields and purities (Scheme 2).

The ${ }^{1} \mathrm{H}$, and ${ }^{13} \mathrm{C}$ NMR spectroscopic data (chemical shifts and DEPT), the HPLC-MS analyses and the spectroscopic comparison with previously synthesized bis-thiadiazinane-2thione derivatives ${ }^{20,21,27}$ allowed us to confirm the structure of the new bis-THTT-tripeptides 13a,b. The signals corresponding to the ring methylene protons H-4 and H-6 appear overlapped in multiplets centered at $\sim 4.5 \mathrm{ppm}$, which are complex due to the presence of near stereogenic centers in the tripeptide sequence attached to $\mathrm{N}-5$, and could not be resolved even using a 500 MHz equipment.
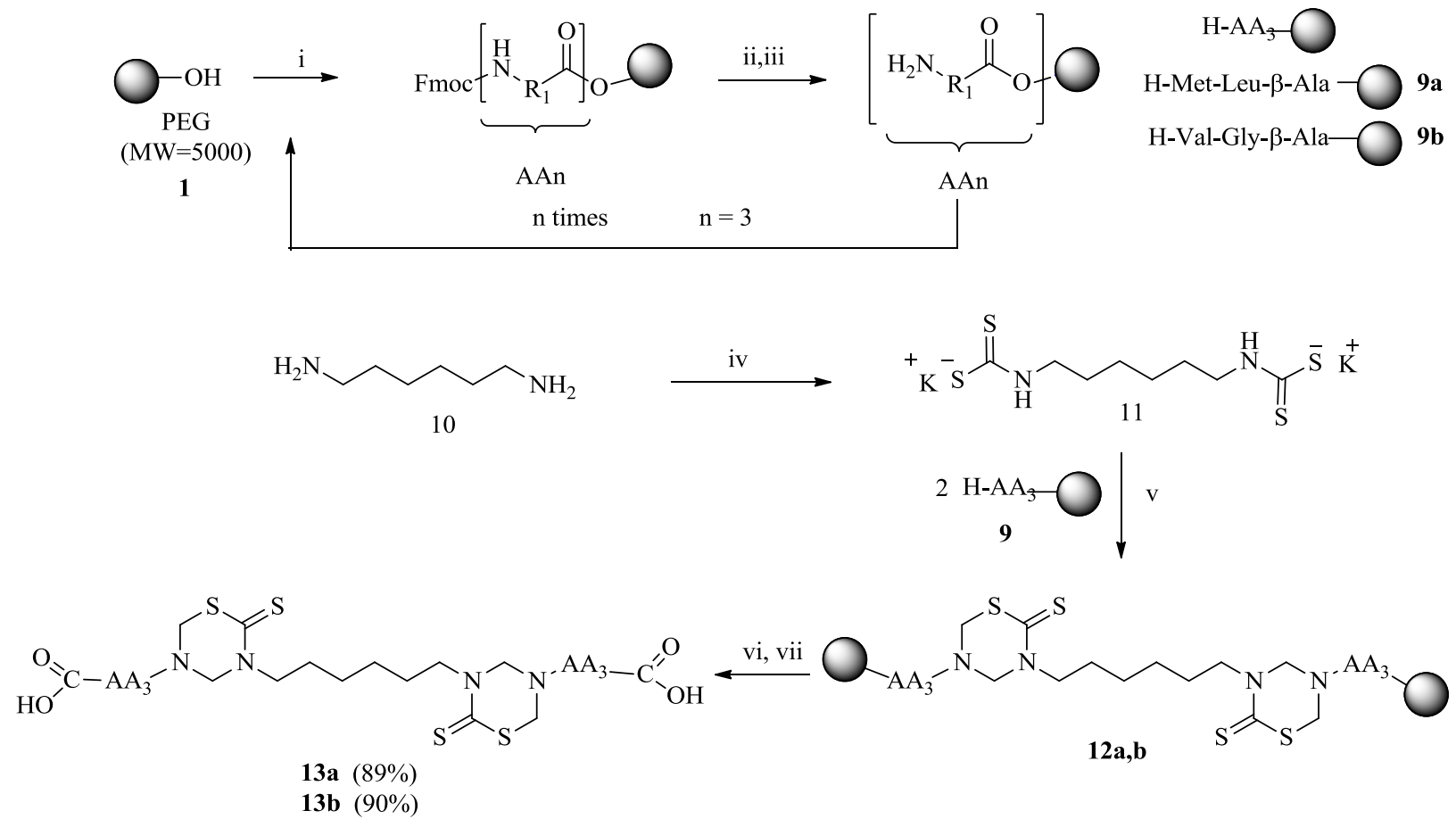

Scheme 2. LPOS of hybrid structures bis-THTT-tripeptides 13a,b. (i) LPP coupling; (ii) Fmocdeprotect; (iii) Precipitate by addition of diethyl ether; (iv) $\mathrm{CS}_{2}, \mathrm{KOH}(20 \%), \mathrm{H}_{2} \mathrm{O}$; (v) $2 \mathrm{HCHO}$, $\mathrm{MeOH}$; (vi) $\mathrm{NaOH} 0.5 \mathrm{~N}$; (vii) $\mathrm{HCl} 2 \mathrm{~N}$.

The peptides sequence bound to N-5 does not present remarkable difficulties to be resolved. In the ${ }^{1} \mathrm{H}$ NMR spectra of 13a,b, it has been possible the assignment of the signals corresponding to the carboxy terminal protons appear at $\delta \sim 10.0$, and at $\sim 8.0 \mathrm{ppm}$ a broad signal corresponding to the amide protons of the peptides chains was observed. 
The ${ }^{13} \mathrm{C}$ NMR spectra of these two compounds exhibited signals in the thiocarbonyl, carbonyl, and aliphatic regions. The thiocarbonyl carbons were observed at $\delta \sim 197.0$. The $\mathrm{COOH}$ terminal carbon appears at $\delta \sim 177$ and the other carbonyl carbons appear at $\delta \sim 170-175$. The signals corresponding to the thiadiazinane-2-thione rings C-4 and C-6 appear at $\delta \sim 71$ and $\delta$ $\sim 55$, respectively. The chemical shifts of the remaining carbons of the tripeptide sequence attached at N-5 (aliphatic carbons) are in accordance with their nature.

Assignments for the ${ }^{1} \mathrm{H}$ NMR and ${ }^{13} \mathrm{C}$ NMR resonances corresponding to the aliphatic backbone connecting both heterocycles were achieved by comparison with those spectroscopic data found for related products previously reported. ${ }^{29}$ The above experimental data have allowed determining unambiguously the chemical structure of the compounds synthesized.

\section{Conclusions}

In conclusion, we have developed a new and efficient liquid-phase synthesis of 3,5-disubstituted 1,3,5-thiadiazinane-2-thione derivatives by a one-pot cyclization from PEG-supported amino acid or tripeptide reagent, the dithiocarbamate salt intermediate and formaldehyde under basic conditions. The major advantage of this strategy is the fact that only the desired compound is released into the solution with the subsequent simplification of purification workup. Furthermore, this synthetic approach is also valid for the preparation of hybrid compounds endowed with two THTT rings connected through the N-3 atoms, which are obtained in good yields and high chemical purity. In our opinion, this is an example of the versatility of the PEG polymer also favoring intramolecular reactions.

To sum up, this methodology paves the way to design a complex thiadiazinane-like library provided the great variety of available amino acid building blocks for the peptide sequence, and the presence of two points of diversity located at nitrogen N-3 and N-5 of the THTT ring.

\section{Experimental Section}

General. Commercially available starting materials and reagents were purchased from commercial sources (Aldrich, Merck, and $\mathrm{BDH}$ ) and were used without further purification. All solvents were dried following standard procedures. Melting points were determined in capillary tubes in an Electrothermal C14500 apparatus and are uncorrected. The progress of the reaction was monitored by TLC analytical silica gel plates $\left(\right.$ Merck $\left.60 \mathrm{~F}_{254}\right)$ using methanol:acetic acid (4:1) as eluent. HPLC was performed using a Waters Alliance 2695 (Waters, MA, USA) chromatography system with a PDA 995 detector, a reverse-phase Symmetry C18 (4.6 x 150 mm) 5-mm column, and $\mathrm{H}_{2} \mathrm{O}$ with $0.045 \%$ TFA and $\mathrm{MeCN}$ with $0.036 \%$ TFA as mobile phases and detection at $220 \mathrm{~nm}$ for the tripeptides. HPLC-MS was performed using a Waters Alliance 2796 with UV/Vis detector 2487 and ESI-MS Micromass ZQ (Waters) chromatography system, 
a reversed-phase Symmetry $300 \mathrm{C} 18(3.9 \times 150 \mathrm{~mm}) 5-\mu \mathrm{m}$ column, and $\mathrm{H}_{2} \mathrm{O}$ with $0.1 \%$ formic acid and $\mathrm{MeCN}$ with $0.07 \%$ formic acid as mobile phases. The NMR spectra were recorded on a Mercury 400 spectrometer $\left[400 \mathrm{MHz}\left({ }^{1} \mathrm{H}\right)\right.$ and $\left.100.6 \mathrm{MHz}\left({ }^{13} \mathrm{C}\right)\right]$. Chemical shifts are given as $\delta$ values against tetramethylsylane as the internal standard and $J$ values are given in $\mathrm{Hz}$. Microanalysis was performed in a Perkin-Elmer $2400 \mathrm{CHN}$.

PEG-Bound aminoacid (4a-d). Polymer support 1 (5 g, $1 \mathrm{mmol})$ dissolved in $10 \mathrm{~mL}$ of $N, N$ dimethylformamide (DMF) was coupled with the corresponding Fmoc-protected amino acids (2a-d) (4 mmol) under DIC/DMAP (4 mmol $0.072 \mathrm{mmol}^{-1}$ ) activation condition for $45 \mathrm{~min}$ at room temperature. To the reaction mixture was added cold diethyl ether in order to precipitate PEG-supported intermediates 3a-d, which was filtered out and washed with cold diethyl ether (3 x $30 \mathrm{~mL}$ ) to remove unreacted reagents and side-products. Deprotection of compounds 3a-d was performed with $20 \%$ piperidine $(2 \mathrm{~mL})$ in $8 \mathrm{~mL}$ of DMF at room temperature. After the mixture was stirred for 20 minutes, the polymer was precipitated by addition of cold diethyl ether (60 $\mathrm{mL}$ ) and for completion of the precipitation, the suspension was left at $0^{\circ} \mathrm{C}$ for another $30 \mathrm{~min}$, the precipitate was collected, washed with diethyl ether ( 3 × $30 \mathrm{~mL}$ of each), and dried in vacuo to afford the PEG-bound free amine 4a-d.

\section{General procedure for the liquid phase organic synthesis of 3,5-disubstituted 1,3,5- thiadiazinane-2-thione derivatives (8a-h)}

To a stirred solution of the corresponding amine $(0.01 \mathrm{~mol}$, ciclohexylamine 5a or furfurylamine 5b) in $25 \mathrm{~mL}$ of water, $1.1 \mathrm{~g}(0.01 \mathrm{~mol})$ of potassium hydroxide (as a $20 \%$ aqueous solution) and $0.6 \mathrm{~mL}(0.01 \mathrm{~mol})$ of carbon disulfide were added at room temperature. The mixture was subsequently stirred for 4 hours. Then $1.2 \mathrm{~mL}(0.02 \mathrm{~mol})$ of formaldehyde solution (37\%), was added and the stirring continued for 1 hour. The mixture was filtered out and the resulting solution added dropwise to a suspension of $0.01 \mathrm{~mol}$ of $\mathbf{4 a - d}$ in $10 \mathrm{ml}$ of a pH 7.8-8 phosphate buffer solution. After the mixture was stirred for two hours, the polymer bound THTT 7a-h was extracted with dichloromethane $(3 \times 5 \mathrm{~mL})$, the organic solution was rotoevaporated and the polymer was precipitated by addition of cold diethyl ether $(30 \mathrm{~mL})$. To achieved a total precipitation, the suspension was left at $0^{\circ} \mathrm{C}$ for another $30 \mathrm{~min}$, the precipitate was collected, washed with diethyl ether (3 x $10 \mathrm{~mL}$ of each), to afford the PEG-bound THTT 7a-h. After drying in vacuo, the solid was added to the $\mathrm{NaOH}$ solution $(0.5 \mathrm{~N})$ to cleave the products at room temperature overnight. The aqueous solution was cooled in an ice-bath and acidified to $\mathrm{pH} 2$ by $15 \%$ hydrochloric acid. Finally, the precipitate was filtered and washed with a cool diethyl ether $(3 \times 5 \mathrm{~mL})$.

5-Carboxymethyl-3-cyclohexyl-1,3,5-thiadiazinane-2-thione (8a). White solid, 40\% yield, mp $154{ }^{\circ} \mathrm{C}$ (d) (lit. ${ }^{14}$ yield 20\%, mp $154{ }^{\circ} \mathrm{C}(\mathrm{d})$ ). ${ }^{1} \mathrm{H}$ NMR (DMSO- $d_{6}$ ) $\delta 12.00$ (brs, $1 \mathrm{H}, \mathrm{OH}$ ), 5.62 [tt, J $11.7 \mathrm{~Hz}, J 4.2 \mathrm{~Hz}, 1 \mathrm{H}, \mathrm{CH}$ (cyclohexyl residue)], 4.45 (s, 2H, N-CH2-N), 4.45 (s, 2H, N$\mathrm{CH}_{2}-\mathrm{S}$ ), 3.47 ( s, 2H, $\mathrm{CH}_{2}-\mathrm{CO}$ [Gly residue]), 1.80-1.00 [m, 10H, 5 x $\mathrm{CH}_{2}$ (cyclohexyl residue)]. 
${ }^{13} \mathrm{C}$ NMR (DMSO- $\left.d_{6}\right) \delta 190.0(\mathrm{C}=\mathrm{S}), 170.6(\mathrm{C}=\mathrm{O}), 64.4\left(\mathrm{CH}_{2}\right), 57.5\left(\mathrm{CH}_{2}\right), 57.1\left(\mathrm{CH}_{2}\right), 50.2$ $(\mathrm{CH}), 28.0\left(2 \times \mathrm{CH}_{2}\right), 25.2\left(2 \times \mathrm{CH}_{2}\right), 24.7\left(\mathrm{CH}_{2}\right)$.

5-Carboxyethyl-3-cyclohexyl-1,3,5-thiadiazinane-2-thione (8b). White solid, $64 \%$ yield, $\mathrm{mp}$ $145-146{ }^{\circ} \mathrm{C}$ (lit. ${ }^{14}$ yield $64 \%$, mp 145-146 ${ }^{\circ} \mathrm{C}$ ). ${ }^{1} \mathrm{H}$ NMR (DMSO- $d_{6}$ ) $\delta 12.15$ (brs, $1 \mathrm{H}, \mathrm{OH}$ ), 5.59 [tt, $J 11.7 \mathrm{~Hz}, J 4.2 \mathrm{~Hz}, 1 \mathrm{H}, \mathrm{CH}$ (cyclohexyl residue)], $4.42\left(\mathrm{~s}, 2 \mathrm{H}, \mathrm{N}-\mathrm{CH}_{2}-\mathrm{N}\right), 4.40(\mathrm{~s}, 2 \mathrm{H}, \mathrm{N}-$ $\mathrm{CH}_{2}-\mathrm{S}$ ), $2.84\left[\mathrm{t}, J 7.0 \mathrm{~Hz}, 2 \mathrm{H}, \mathrm{N}-\mathrm{CH}_{2}\right.$ [ $\beta$-Ala residue)], 2.49 ( t, $J 7.0 \mathrm{~Hz}, 2 \mathrm{H}, \mathrm{CH}_{2}-\mathrm{CO}$ [ $\beta$-Ala residue ]), $1.80-1.00\left[\mathrm{~m}, 10 \mathrm{H}, 5 \times \mathrm{CH}_{2}\right.$ (cyclohexyl residue)]. ${ }^{13} \mathrm{C}$ NMR (DMSO- $d_{6}$ ) $\delta 191.4$ $(\mathrm{C}=\mathrm{S}), 174.4(\mathrm{C}=\mathrm{O}), 66.0\left(\mathrm{CH}_{2}\right), 59.0\left(\mathrm{CH}_{2}\right), 58.0\left(\mathrm{CH}_{2}\right), 46.7(\mathrm{CH}), 34.1\left(\mathrm{CH}_{2}\right), 29.3\left(2 \times \mathrm{CH}_{2}\right)$, $26.7\left(2 \times \mathrm{CH}_{2}\right), 26.1\left(\mathrm{CH}_{2}\right)$.

5-Carboxypentyl-3-cyclohexyl-1,3,5-thiadiazinane-2-thione (8c). White solid, 65\% yield, $\mathrm{mp}$ 106-108 ${ }^{\circ} \mathrm{C}$ (lit. ${ }^{14}$ yield $30 \%$, mp 106-108 ${ }^{\circ} \mathrm{C}$ ). ${ }^{1} \mathrm{H}$ NMR (DMSO- $d_{6}$ ): $\delta 11.99$ (brs, $1 \mathrm{H}, \mathrm{OH}$ ), 5.63 [tt, $J 11.7 \mathrm{~Hz}, J 4.2 \mathrm{~Hz}, 1 \mathrm{H}, \mathrm{CH}$ (cyclohexyl residue)], $4.41\left(\mathrm{~s}, 2 \mathrm{H}, \mathrm{N}-\mathrm{CH}_{2}-\mathrm{N}\right), 4.39(\mathrm{~s}, 2 \mathrm{H}, \mathrm{N}-$ $\mathrm{CH}_{2}-\mathrm{S}$ ), 2.59 [t, $J 7.10 \mathrm{~Hz}, 2 \mathrm{H}, \mathrm{N}-\mathrm{CH}_{2}$ (hexanoic residue)], $2.20\left[\mathrm{t}, J 7.27 \mathrm{~Hz}, 2 \mathrm{H}, \mathrm{CH}_{2}-\mathrm{CO}\right.$ (hexanoic residue)], 1.83-112 [m, 16H, $8 \times \mathrm{CH}_{2}$ (cyclohexyl residue and hexanoic residue)]. ${ }^{13} \mathrm{C}$ NMR (DMSO- $\left.d_{6}\right) \delta 190.0(\mathrm{C}=\mathrm{S}), 174.5(\mathrm{C}=\mathrm{O}), 64.6\left(\mathrm{CH}_{2}\right), 56.2\left(\mathrm{CH}_{2}\right), 48.7\left(\mathrm{CH}_{2}\right), 57.5\left(\mathrm{CH}_{2}\right)$, $33.6\left(\mathrm{CH}_{2}\right), 27.9\left(2 \times \mathrm{CH}_{2}\right), 26.5\left(\mathrm{CH}_{2}\right), 26.05\left(\mathrm{CH}_{2}\right), 25.3\left(2 \times \mathrm{CH}_{2}\right), 24.6\left(\mathrm{CH}_{2}\right), 24.3\left(\mathrm{CH}_{2}\right)$.

(11S)-5-[( $\alpha$-Isobutyl)carboxymethyl-3-Cyclohexyl]-1,3,5-thiadiazinane-2-thione (8d). White solid, 56\% yield, mp $162{ }^{\circ} \mathrm{C} \mathrm{d}$ (lit. ${ }^{14}$ yield $52 \%$, mp $161{ }^{\circ} \mathrm{C} \mathrm{d}$ ). ${ }^{1} \mathrm{H}$ NMR (DMSO- $d_{6}$ ): $\delta 12.16$ (brs, 1H, OH), 5.60 [tt, $J 11.66 \mathrm{~Hz}, J 4.19 \mathrm{~Hz}, 1 \mathrm{H}, \mathrm{CH}$ (cyclohexyl residue)], 4.43 (s, 2H, N$\mathrm{CH}_{2}-\mathrm{N}$ ), 4.41 (s, 2H, N-CH $2-\mathrm{S}$ ), 3.32 [t, J 7.0 Hz, 1H, N-CH (Leu residue)], 1.80-1.09 [m, 13H, $6 \times \mathrm{CH}_{2}$ (cyclohexyl and Leu residue) and $\mathrm{CH}$ (Leu residue)], $0.83\left(\mathrm{~m}, 6 \mathrm{H}, 2 \times \mathrm{CH}_{3}\right.$ (Leu residue)]. ${ }^{13} \mathrm{C}$ NMR (DMSO- $\left.d_{6}\right) \delta 191.4(\mathrm{C}=\mathrm{S}), 172.6(\mathrm{C}=\mathrm{O}), 63.2\left(\mathrm{CH}_{2}\right), 58.2\left(\mathrm{CH}_{2}\right), 53.8$ $(\mathrm{CH}), 46.7(\mathrm{CH}), 38.0(\mathrm{CH}), 34.1\left(\mathrm{CH}_{2}\right), 29.3\left(2 \times \mathrm{CH}_{2}\right), 26.7\left(2 \times \mathrm{CH}_{2}\right), 26.1\left(\mathrm{CH}_{2}\right), 23.1\left(\mathrm{CH}_{3}\right)$, $21.2\left(\mathrm{CH}_{3}\right)$.

5-Carboxymethy- 3-(2'-furfurylmethyl)-1,3,5-thiadiazinane-2-thione (8e). White solid, 56\% yield, mp $132-133{ }^{\circ} \mathrm{C} \mathrm{d}$ (lit. ${ }^{14}$ yield $50 \%$, mp $133-134{ }^{\circ} \mathrm{C} \mathrm{d}$ ). ${ }^{1} \mathrm{H}$ NMR (DMSO- $d_{6}$ ): $\delta 12.66$ (brs, $1 \mathrm{H}, \mathrm{OH}), 7.58$ [m, 1H, CH-O (furfuryl residue)], 6.41 [d, J $3.42 \mathrm{~Hz}, 1 \mathrm{H}, \mathrm{CH}$ (furfuryl residue)], 6.39 [d, J $3.42 \mathrm{~Hz}, 1 \mathrm{H}, \mathrm{CH}$ (furfuryl residue)], $4.56\left(\mathrm{~s}, 2 \mathrm{H}, \mathrm{N}-\mathrm{CH}_{2} \mathrm{~S}\right.$ ), $5.27\left(\mathrm{~s}, 2 \mathrm{H}, \mathrm{CH}_{2}\right), 4.54(\mathrm{~s}$, $\left.2 \mathrm{H}, \mathrm{N}_{-} \mathrm{CH}_{2}-\mathrm{N}\right), 3.38\left(\mathrm{~s}, 2 \mathrm{H}, \mathrm{CH}_{2}\right) .{ }^{13} \mathrm{C} \mathrm{NMR}\left(\mathrm{DMSO}_{-} d_{6}\right) \delta 191.6(\mathrm{C}=\mathrm{S}), 170.4(\mathrm{C}=\mathrm{O}), 148.72$ $(\mathrm{C}), 143.0(\mathrm{CH}), 110.60(\mathrm{CH}), 109.68(\mathrm{CH}), 69.1\left(\mathrm{CH}_{2}\right), 58.5\left(\mathrm{CH}_{2}\right), 50.5\left(\mathrm{CH}_{2}\right), 46.4\left(\mathrm{CH}_{2}\right)$.

5-Carboxymethy- 3-(2'-furfurylmethyl)-1,3,5-thiadiazinnae-2-thione (8f). White solid, 66\% yield, mp 131-132 ${ }^{\circ} \mathrm{C} \mathrm{d}$ (lit. ${ }^{14}$ yield $65 \%$, mp $131-132{ }^{\circ} \mathrm{C} \mathrm{d}$ ). ${ }^{1} \mathrm{H}$ NMR (DMSO- $d_{6}$ ): $\delta 12.21$ (brs, $1 \mathrm{H}, \mathrm{OH}), 7.60$ [m, 1H, CH-O (furfuryl residue)], 6.42 [d, J $3.42 \mathrm{~Hz}, 1 \mathrm{H}, \mathrm{CH}$ (furfuryl residue)], $6.41\left[\mathrm{~d}, J 3.42 \mathrm{~Hz}, 1 \mathrm{H}, \mathrm{CH}\right.$ (furfuryl residue)], $5.51\left(\mathrm{~s}, 2 \mathrm{H}, \mathrm{N}_{-} \mathrm{CH}_{2}-\mathrm{S}\right), 5.28\left(\mathrm{~s}, 2 \mathrm{H}, \mathrm{CH}_{2}\right), 4.52(\mathrm{~s}$, $\left.2 \mathrm{H}, \mathrm{N}-\mathrm{CH}_{2}-\mathrm{N}\right), 2.80$ [t, J $6.96 \mathrm{~Hz}, 2 \mathrm{H}, \mathrm{N}-\mathrm{CH}_{2}$ ( $\beta$-Ala residue)], 2.35 [t, $J 6.96 \mathrm{~Hz}, 2 \mathrm{H}, \mathrm{CH}_{2}-\mathrm{CO}$ ( $\beta$-Ala residue)]; ${ }^{13} \mathrm{C}$ NMR (DMSO- $\left.d_{6}\right) \delta 191.8(\mathrm{C}=\mathrm{S}), 173.0(\mathrm{C}=\mathrm{O}), 149.0\left(\mathrm{CH}_{2}\right), 143.0(\mathrm{CH})$, $110.7(\mathrm{CH}), 109.8(\mathrm{CH}), 68.7\left(\mathrm{CH}_{2}\right), 58.1\left(\mathrm{CH}_{2}\right), 46.3\left(\mathrm{CH}_{2}\right), 45.5\left(\mathrm{CH}_{2}\right), 32.2\left(\mathrm{CH}_{2}\right)$.

5-Carboxypentyl-3-(2'-furfurylmethyl)-1,3,5-thiadiazinane-2-thione (8g). White solid, 68\% yield, mp 100-101 ${ }^{\circ} \mathrm{C} \mathrm{d}$ (lit. ${ }^{14}$ yield $63 \%$, mp 99-100 ${ }^{\circ} \mathrm{C} \mathrm{d}$ ). ${ }^{1} \mathrm{H}$ NMR (DMSO- $d_{6}$ ): $\delta 12.21$ (brs, $1 \mathrm{H}, \mathrm{OH}$ ), ), $7.63[\mathrm{~m}, 1 \mathrm{H}, \mathrm{CH}-\mathrm{O}$ (furfuryl residue)], $6.44[\mathrm{~d}, J 3.42 \mathrm{~Hz}, 1 \mathrm{H}, \mathrm{CH}$ (furfuryl 
residue)], 6.43 [d, J $3.42 \mathrm{~Hz}, 1 \mathrm{H}, \mathrm{CH}$ (furfuryl residue)], 5.29 (s, 2H, N-CH2), 4.49 (s, 2H, N$\mathrm{CH}_{2}-\mathrm{S}$ ), 4.51 (s, 2H, N-CH$\left.-\mathrm{N}\right), 2.50$ [t, J 7.10 Hz, 2H, N-CH (hexanoic residue)], 2.17 [t, $J$ $7.27 \mathrm{~Hz}, 2 \mathrm{H}, \mathrm{CH}_{2}-\mathrm{CO}$ (hexanoic residue)], $1.45\left(2 \mathrm{H}, \mathrm{m}, \mathrm{CH}_{2}\right.$ hexanoic residue), 1.30 (2H, $\mathrm{m}$, $\mathrm{CH}_{2}$ hexanoic residue), $1.25\left(2 \mathrm{H}, \mathrm{m}, \mathrm{CH}_{2}\right.$ hexanoic residue). ${ }^{13} \mathrm{C}$ NMR (DMSO- $\left.d_{6}\right) \delta 191.8$ $(\mathrm{C}=\mathrm{S}), 174.5(\mathrm{C}=\mathrm{O}), 148.9(\mathrm{C}), 142.9(\mathrm{CH}), 110.6(\mathrm{CH}), 109.8(\mathrm{CH}), 68.3\left(\mathrm{CH}_{2}\right) .58 .3\left(\mathrm{CH}_{2}\right)$. $49.0\left(\mathrm{CH}_{2}\right), 46.2\left(\mathrm{CH}_{2}\right), 33.6\left(\mathrm{CH}_{2}\right), 26.2\left(\mathrm{CH}_{2}\right), 26.0\left(\mathrm{CH}_{2}\right), 24.2\left(\mathrm{CH}_{2}\right)$.

\section{(12S)-5-[( $\alpha$-Isobutyl)]carboxylmethyl-3-(2'-furfurylmethyl-1,3,5-thiadiazinane-2-thione}

(8h). White solid, 60\% yield, mp 125-126 ${ }^{\circ} \mathrm{C}$ (lit. ${ }^{14}$ yield $61 \%$, mp 125-127 ${ }^{\circ} \mathrm{C}$ ). ${ }^{1} \mathrm{H}$ NMR $\left(\mathrm{DMSO}-d_{6}\right) \delta 12.24$ (brs, $\left.1 \mathrm{H}, \mathrm{OH}\right), 7.62$ [1H, m, CH-O (furfuryl residue)], 6.45 [d, J $3.53 \mathrm{~Hz}$, $1 \mathrm{H}, \mathrm{CH}$ (furfuryl residue)], $6.42\left[\mathrm{~d}, J 3.53 \mathrm{~Hz}, 1 \mathrm{H}, \mathrm{CH}\right.$ (furfuryl residue)], $5.24\left(\mathrm{~s}, 2 \mathrm{H}, \mathrm{CH}_{2}\right.$ ), $4.60\left(\mathrm{~s}, 2 \mathrm{H}, \mathrm{N}-\mathrm{CH}_{2}-\mathrm{N}\right) .4 .55$ (s, 2H, N-CH $\left.2-\mathrm{S}\right), 3.47$ [t, J 6.5 Hz, 1H, CH (Leu residue)], 1.36 [m, $3 \mathrm{H}, \mathrm{CH}_{2}$ and $\mathrm{CH}$ (Leu residue)], $0.81\left[6 \mathrm{H}, \mathrm{m}, 2 \times \mathrm{CH}_{3}\right.$ (Leu residue)]. ${ }^{13} \mathrm{C}$ NMR (DMSO- $\left.d_{6}\right) \delta$ $192.0(\mathrm{C}=\mathrm{S}), 173.2(\mathrm{C}=\mathrm{O}), 148.8(\mathrm{C}), 143.0(\mathrm{CH}), 110.7(\mathrm{CH}), 110.0(\mathrm{CH}), 66.5\left(\mathrm{CH}_{2}\right), 60.6$ $(\mathrm{CH}), 56.3\left(\mathrm{CH}_{2}\right), 46.4\left(\mathrm{CH}_{2}\right), 38.1\left(\mathrm{CH}_{2}\right), 24.7(\mathrm{CH}), 23.3\left(\mathrm{CH}_{3}\right), 21.6\left(\mathrm{CH}_{3}\right)$.

Preparation of PEG-bound tripeptide sequence (9a,b). The tripeptide sequences (9a,b) was synthesized with the standard Fmoc/t-Bu strategy. The coupling and deprotection steps (Fmocaminoacid, DIC, DMAP) was previously described. After each cycle of coupling/deprotection, $15 \mathrm{~mL}$ of diethyl ether was added in order to precipitate PEG-supported intermediates, which was filtered and washed with cold diethyl ether $(2 \times 10 \mathrm{~mL})$ to remove un-reacted reagents and side products. After the last deprotection step, the polymer bound peptide was dried under reduced pressure. The purity of the two crude peptides $(\mathbf{9 a}, \mathbf{b})$ were checked by RP-HPLC (UV absorbance at $220 \mathrm{~nm}$ ) and analyzed by HPLC-MS, after the cleavage treatment of one $\mathrm{mg}$ of PEG bound at peptide sequence.

Sequence 9a, Met-Leu- $\beta$-Ala-OH. Yield 85\%; Purity 92.4\%; Retention time 7.05 min.; MS [M $+\mathrm{H}]^{+}, 334.29$ calculated for $\mathrm{C}_{14} \mathrm{H}_{27} \mathrm{~N}_{3} \mathrm{O}_{4} \mathrm{~S}, 334.18$.

Sequence 9b, Val-Gly- $\beta$-Ala-OH. Yield 84\%; Purity 90.3\%; Retention time 6.14 min.; MS [M + $\mathrm{H}]^{+} 246.34$ calculated for $\mathrm{C}_{10} \mathrm{H}_{19} \mathrm{~N}_{3} \mathrm{O}_{4}$, theoretical 246.14 .

General procedure for the liquid phase organic synthesis of the two hybrid structures bisTHTT-tripeptides (13a,b)

To a stirred solution of 1,6-diaminohexane $(1 \mathrm{mmol})$ in $10 \mathrm{~mL}$ of methanol, potassium hydroxide ( $2 \mathrm{mmol}, 0.11 \mathrm{~g}$, ) and carbon disulfide $(0.12 \mathrm{~mL}, 2 \mathrm{mmol})$ were added at room temperature. The mixture was subsequently stirred for $4 \mathrm{~h}$. Then, formaldehyde solution $37 \%(0.32 \mathrm{ml}, 4 \mathrm{mmol})$ was added and the stirring continued for $1 \mathrm{~h}$. The reaction mixture was added dropwise to a suspension of the corresponding PEG-Bound tripeptide sequence (9a,b) (2 mmol) in a pH 7.8 buffer solution of phosphate $(10 \mathrm{~mL})$ and stirred for 24 hours. The polymer bound hybrid compound (12a,b) was precipitated by addition of cold diethyl ether ( $20 \mathrm{~mL})$, and for completion of the precipitation, the suspension was left at $0{ }^{\circ} \mathrm{C}$ for another $30 \mathrm{~min}$, the precipitate was collected and washed with diethyl ether $(2 \times 10 \mathrm{~mL}$ of each). After drying in vacuum, the solid 
was added to the $\mathrm{NaOH}$ solution $(0.5 \mathrm{~N})$ to cleave the products at room temperature overnight. The aqueous solution was cooled in an ice-bath and acidified to $\mathrm{pH} 2 \mathrm{using} 15 \% \mathrm{HCl}$. Finally, the precipitate was filtered and washed with a cool diethyl ether $(3 \times 5 \mathrm{ml})$ to afford the corresponding bis-THTT-tripeptide.

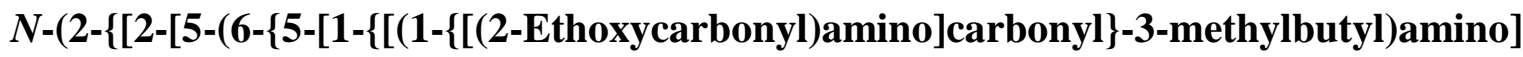
carbonyl\}-3-(methylsulfanyl)propyl]-2-thioxo-1,3,5-thiadiazinan-3-yl\}hexyl)-6-thioxo-1,3,5thiadiazinan-3-yl]-4-(methylsulfanyl)butanoyl]amino -4-methylpentanoyl)- $\beta$-alanine. (13a). White solid, 89\% yield, mp 121-122 ${ }^{\circ} \mathrm{C} .{ }^{1} \mathrm{H}$ NMR (DMSO- $\left.d_{6}\right) \delta 11.00$ (brs, 2H, 2 x OH), 8.00 (brs, 4H, 4 x NH), 4.33 (s, 4H, 2 x N-CH2-N), 4.21 (s, 4H, 2 x N-CH $-\mathrm{S}$ ), 3.99 [m, 2H, 2 x N-CH (Leu residues)], $3.82\left[\mathrm{~m}, 4 \mathrm{H}, 2 \times \mathrm{N}-\mathrm{CH}_{2}-\mathrm{C}\right.$ (hexyl chain)], $3.72\left[\mathrm{~m}, 4 \mathrm{H}, 2 \times \mathrm{N}-\mathrm{CH}_{2}(\beta-\mathrm{Ala}\right.$ residues)], 2.58 [t, $J 16.5 \mathrm{~Hz}, 4 \mathrm{H}, 2 \times \mathrm{CH}_{2}-\mathrm{CO}$ ( $\beta$-Ala residues)], 2.39 [t, $J 7.2 \mathrm{~Hz}, 4 \mathrm{H}, 2 \times \mathrm{S}-\mathrm{CH}_{2}$ (Met residues)], 2.03 [m, 4H, $2 \times \mathrm{N}-\mathrm{CH}$ (Met residues) and $2 \times \mathrm{N}-\mathrm{CH}$ (Leu residues)], 1.98 [s, $6 \mathrm{H}, 2 \times \mathrm{CH}_{3}$ (Met residues)], 1.71 [m, 4H, $2 \times$ C- $\mathrm{CH}_{2}-\mathrm{C}$ (Met residues)], 1.60-1.48 [8H, 4 x $\mathrm{CH}_{2}$ (hexyl chain)], 1.25 [m, 4H, $2 \times \mathrm{CH}_{2}$ (Leu residues)], 0.90 [m, 12H, $4 \times \mathrm{CH}_{3}$ [Leu residues]). ${ }^{13} \mathrm{C}$ NMR (DMSO- $\left.d_{6}\right) \delta 197.9(2 \times \mathrm{C}=\mathrm{S}), 177.3(2 \times \mathrm{COOH}), 173.9$ [2 x C=O (Met residues)], 171.6 [2 x C=O (Leu residues)], $71.8\left(2 \times \mathrm{N}_{-} \mathrm{CH}_{2}-\mathrm{N}\right), 60.3$ [2 x CH (Met residues)], $55.7\left(2 \times \mathrm{N}^{-\mathrm{CH}_{2}-}\right.$ $\mathrm{S}), 48.5$ [2 x CH 2 (hexyl chain)], 47.2 (2 x N-CH (Leu residues)], 41.2 [2 x $\mathrm{CH}_{2}$ (Leu residues)], 37.8 [2 x N-CH 2 ( $\beta$-Ala residues)], 36.0 [2x $\mathrm{CH}_{2}-\mathrm{CO}$ ( $\beta$-Ala residues)], 29.9 [2 x S- $\mathrm{CH}_{2}$ [Met residues)], 29.4 [2 x CH (Met residues)], 26.9 [2 x CH 2 (hexyl chain)], 26.5 [2 x $\mathrm{CH}_{2}$ (hexyl chain)], 22.5 [2 x CH (Leu residues]), 19.8 [4 x CH 3 (Leu residues)], 15.2 [2 x $\mathrm{CH}_{3}$ (Met residues)]. ESI-MS [M+H] $]^{+}$, 983.56, calculated for $\mathrm{C}_{40} \mathrm{H}_{71} \mathrm{~N}_{8} \mathrm{O}_{8} \mathrm{~S}_{6}$ 983.37. Anal. Calcd for $\mathrm{C}_{40} \mathrm{H}_{70} \mathrm{~N}_{8} \mathrm{O}_{8} \mathrm{~S}_{6}$ (982.36): C, 48.85; H, 7.17; N, 11.39\%. Found: C, 48.90; H, 7.23; N, $11.34 \%$.

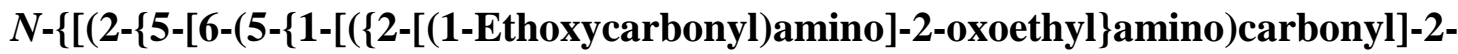
methylpropyl\}-2-thioxo-1,3,5-thiadiazinan-3-yl)hexyl]-6-thioxo-1,3,5-thiadiazinan-3-yl\}-3methylbutanoyl)amino] acetyl \}alanine. (13b). White solid; $90 \%$ yield, mp 109-110 ${ }^{\circ} \mathrm{C} .{ }^{1} \mathrm{H}$ NMR (DMSO- $\left.d_{6}\right) \delta 10.05$ (brs, 2H, $2 \times$ OH), 8.35 (brs, 4H, 4 x NH), 4.64 [m, 2H, 2 x CH (Ala residues)], 4.09 [d, J $16.3 \mathrm{~Hz}, 4 \mathrm{H}, 2 \times \mathrm{CH}_{2}$ (Gly residues)], 3.94 (s, 4H, $2 \times \mathrm{N}_{-} \mathrm{CH}_{2}-\mathrm{N}$ ), 3.62 (s, $4 \mathrm{H}, 2 \times \mathrm{N}-\mathrm{CH}_{2}-\mathrm{S}$ ), 3.55 [s, 2H, $2 \times \mathrm{N}-\mathrm{CH}$ (Val residues)], 2.55 [t, J $7.25 \mathrm{~Hz} 4 \mathrm{H}, 2 \times \mathrm{N}-\mathrm{CH}_{2}$ (hexyl chain)], 2.29 [d, J 2.6 Hz, 2H, 2 x CH (Val residues)], 1.35 [m, 10H, 2 x $\mathrm{CH}_{2}$ (hexyl chain) and $2 \mathrm{x} \mathrm{CH}_{3}$ (Ala residues)], 1.29 [m, 4H, $2 \times \mathrm{CH}_{2}$ (hexyl chain)], 1.01 [12H, m, $4 \times \mathrm{CH}_{3}$ (Val residues)]; ${ }^{13} \mathrm{C}$ NMR (DMSO- $\left.d_{6}\right) \delta 197.9(2 \times \mathrm{C}=\mathrm{S}), 177.0(2 \times \mathrm{COOH}), 175.0[2 \times \mathrm{C}=\mathrm{O}$ (Val residues)], 170.9 [2 x C=O (Gly residues)], $71.8\left(2 \times \mathrm{N}_{-} \mathrm{CH}_{2}-\mathrm{N}\right), 66.9$ [2 x N-CH (Val residues)], 56.0 ( $\left.2 \times \mathrm{N}_{-} \mathrm{CH}_{2}-\mathrm{S}\right), 53.7$ [2 x CH (Ala residues)], 49.1 [2 x N-CH (hexyl chain)], 28.5 [ $2 \mathrm{x} \mathrm{CH}_{2}$ (hexyl chain)], 27.4 [2 $\mathrm{x} \mathrm{CH}_{2}$ (hexyl chain)], 25.7 [2 x $\mathrm{CH}$ [Val residues)], 16.8 [4 $x \mathrm{CH}_{3}$ (Val residues)), 16.3 [2 $\mathrm{x} \mathrm{CH}_{3}$ (Ala residues)]; ESI-MS [M + H] ${ }^{+}$807.22; calculated for $\mathrm{C}_{32} \mathrm{H}_{55} \mathrm{~N}_{8} \mathrm{O}_{8} \mathrm{~S}_{4}$ 807.30. Anal. Calcd for $\mathrm{C}_{32} \mathrm{H}_{54} \mathrm{~N}_{8} \mathrm{O}_{8} \mathrm{~S}_{4}$ (807.08): C, 47.62; H, 6.74; N, $13.88 \%$. Found: C, 47.71; H, 6.80; N, 13.93\%.

\section{Acknowledgements}


This work was supported by the MICINN of Spain (Project CTQ2011-24652, ConsoliderIngenio 2010C-07-25200) and CTQ2009-07758 and the CAM (Project P-PPQ-000225-0505), and the Generalitat de Catalunya (2009SGR 1024). M. Suárez is grateful to SAB2010-0132 from Ministerio de Educación de España.

\section{References}

1. Pattabiraman, V. R.; Bode, J. W. Nature 2011, 480 (7378), 471-479.

2. (a) Vandersteen, A. M.; Han, H.; Janda, K. D. Mol Diversity 1996, 2, 89-96. (b) Wentworth, Jr. P. Trends Biotechnol 1999, 17, 448-452. (c) Annunziata, R.; Benaglia, M.; Cinquini, M.; Cozzi, F. Chem. Eur. J. 2000, 6, 133-138.

3. (a) Colombo, R. Tetrahedron Lett. 1981, 22, 4129-32. (b) Lin, X.; Zhang, J.; Cui, S.; Wang, Y. Synthesis 2003, 1569-1573.

4. Dickerson, T. J.; Reed, N. N.; Janda, K. D. Chem. Rev. 2002, 102, 3325-3344.

5. Gravert, D. J.; Janda, K. D. Chem. Rev. 1997, 97, 489-509.

6. (a) Pillai, V. N. R.; Mutter. M. Acc. Chem. Res. 1981, 14, 122-130. (b) Zhu, J.; Hegedus, L. S. J. Org. Chem. 1995, 60, 5831-5837.

7. (a) Greenwald, R. B. J. J.Control Release 2001, 74, 159-171. (b) Drioli, S.; Adamo, I.; Ballico, M.; Morvan, F.; Bonora, G. B. Eur. J. Org. Chem. 2002, 3473-3480.

8. (a) Sauvagnat, B.; Lamaty, F.; Lazaro, R.; Martinez, J. Tetrahedron Lett. 1998, 39, 821-824.

(b) Yeh, C.; Sun, C. Tetrahedron Lett. 1999, 40, 7247-7250. (c) Huang, K.; Sun, C. Bioorg. Med. Chem. Lett. 2002, 12, 1001-1003. (d) Stoyanov, E. V.; Champavier, Y.; Simon, A.; Basly, J. P. Bioorg. Med. Chem. Lett. 2002, 12, 2685-2687. (e) Xia, M.; Wang, Y. Synthesis 2003, 262-266. (f) Chen, C.; Chen, Y. C. Tetrahedron Lett. 2004, 45, 113-115. (g) Wang, Y.; Lin, X.; Cui, S. Synlett 2004, 1175-1178. (h) Zong, Y.; Wang, J.; Yue, G.; Feng, L.; Song, Z.; Song, H.; Han, Y. Tetrahedron Lett. 2005, 46, 5139-5141. (i) Sheng, S.; Lin, S.; Wang, Q.; Liu, X.; Lin, M. Synthetic Comm. 2007, 37, 1011-1017.(j) She, D.; Yu, H.; Huang, Q.; Li, F.; Li, C. Molecules 2010, 15, 1898-1902.

9. (a) Coro, J.; Pérez, R.; Monzote, L.; Rodríguez, H.; Suárez, M. Open Med. Chem. J. 2011, 5, 51-60. (b) Pérez, R.; Burgos, A.; Jones, D. C.; Andrew, L.; Rodríguez, H.; Suárez, M.; Fairlamb A.; Wishart, D. J. Med. Chem. 2009, 52, 1670-1680. (c) Ozcelik, A. B.; Ersan, S.; Ural, A.U.; Ozkan, S.; Ertan, M. Arzneim. Forsch/Drug Res. 2007, 57, 554-559. (d) Katiyar, D.; Tiwari, V. K.; Tripathi, R. P.; Srivastava, A.; Chaturvedi, V.; Srivastava, R.; Srivastava, B. S. Bioorg. Med. Chem. 2003, 11, 4369-4375.

10. Weaffen, W.; Martin, D.; Shade, W. Pharmazie 1963, 18, 420-426.

11. North, M. J.; Mottran, J. C.; Coombs, G. H.M. J. Parasitol. Today 1990, 6, 270-275.

12. Goksoyr, J. Acta Chem. Scand. 1964, 18, 1341-1352.

13. El-Shorbagi, A-N. Eur. J. Med. Chem. 1994, 29, 11-15 
14. Pérez, R.; Rodríguez, H.; Suárez, M.; Ochoa, C.; Ochoa, E. Arzneim. Forsch/Drug Res. 1999, 49, 764-769.

15. Muelas, S.; Suárez, M.; Pérez, R.; Rodríguez, H.; Ochoa, C.; Escario, J. A.; Gómez, A. Mem. Inst. Oswaldo Cruz, Rio de Janeiro 2002, 97, 269-272.

16. Pérez, R.; Rodríguez, H.; Pérez, E.; Suárez, M.; Reyes, O.; González, L.; López, A.; Ezpelata, O.; Pérez, C.; Ochoa, C. Arzneim. Forsch/Drug Res. 2000, 50, 854-857.

17. Carrasco, R.; Padrón, J.; Pérez, R.; Rodríguez, H.; Suárez, M.; Ochoa, C. J. Pharm. Pharmaceut. Sci. 2005, 8, 586-592.

18. Monzote, L.; Montalvo, A.; Fonseca, L.; Pérez, R.; Suárez, M.; Rodríguez, H. Mem. Inst. Oswaldo Cruz, Rio de Janeiro 2004, 99, 329-330.

19. Monzote, L.; Montalvo, A.; Fonseca, L.; Pérez, R.; Suárez, M.; Rodríguez, H.; Arzneim. Forsch/Drug Res. 2005, 55, 232-238.

20. (a) Coro, J.; Pérez, R.; Rodríguez, H.; Suárez, M.; Vega, C.; Rolon, M.; Montero, D.; Nogal, J. J.; Gómez-Barrio, A. Bioorg. Med. Chem. 2005, 13, 3413-3421. (b) Coro, J.; Atherton, R.; Little, S.; Wharton, H.; Yardeley, V.; Alvarez, A.; Suárez, M.; Pérez, R.; Rodríguez, H. Bioorg. Med. Chem. Lett. 2006, 16, 1312-1315.

21. Coro, J.; Little, S.; Yardley, V.; Suarez. M.; Rodríguez, H.; Martín, N.; Pérez-Piñeiro, R. Arch. Pharm. Chem. Life Sci. 2008, 341, 708-713.

22. El Bialy, S. A. A.; Abdelal, A.M.; El-Shorbagi, A.N.; Kheira, S.M.M. Arch. Pharm. Chem. Live. Sci. 2005, 338, 38-43.

23. Coro, J.; Álvarez-Puebla, R.; Montero, A. L.; Suárez, M.; Martin, N.; Pérez, R. J. Mol. Model. 2008, 14, 641-647.

24. Pérez, R.; Suárez, M.; Ochoa, E.; Rodríguez, H.; Martin, N.; Seoane, C.; Novoa, H.; Blaton, N.; Peeters, O. M.; De Ranter, C. Tetrahedron 2001, 57, 7361-7367.

25. Pérez, R.; Reyes, O.; Suárez, M.; Garay, H. E.; Cruz, L. J.; Rodríguez, H.; Molero-Vilchez, M. D.; Ochoa, C. Tetrahedron Lett. 2000, 41, 613-616.

26. Pérez, R.; Suárez, M.; Rodríguez, H.; Molero, D.; Martín, N.; Martínez, R.; Seoane, C. Magn. Reson. Chem. 2001, 39, 222-224.

27. Martínez, R.; Martín, N.; Seoane, C.; Suárez, M.; Pérez, R.; Rodríguez, H.; Kayali, N. Rapid Commun. Mass Spectrom. 2001, 15, 758-762.

28. Chan W.C.; White P. D. Fmoc solid phase peptide synthesis: A practical approach. In The Practical Approach Series, Hames B. D. Ed.. Oxford University Press: Oxford, 2000, pp 2730.

29. Molero, D.; Coro, J.; Pérez, R.; Suárez, M.; Martínez-Álvarez, R.; Herrera, A.; Martín, N. Magn. Reson. Chem. 2007, 45, 93-98. 